\title{
UPAYA PENGELOLAAN WILAYAH PESISIR DALAM MEWUJUDKAN PERLINDUNGAN DAN KONSERVASI DI TAMAN PESISIR UJUNGNEGORO-ROBAN KABUPATEN BATANG
}

\author{
Ferina Ardhi Cahyani \\ Email: ferinaac@gmail.com \\ Mahasiswa Magister Ilmu Hukum Universitas Sebelas Maret Surakarta \\ Djoko Wahju Winarno \\ Email: wahjuwinarnodjoko@gmail.com \\ Albertus Sentot Sudarwanto \\ Email: alsentotsudarwanto@yahoo.com \\ Dosen Fakultas Hukum Universitas Sebelas Maret Surakarta
}

\begin{abstract}
The aim of this article is to review and analyze the management policy of Ujungnegoro-Roban Coastal Park. This research type is empirical research with qualitative approach. Data source used is primary and secondary data source. Primary data sources were obtained through interviews with officials in the relevant offices, while secondary data was obtained through literature studies. Ujungnegoro-Roban Coastal Park was formed based on the Decree of the Minister of Marine Affairs and Fisheries of the Republic of Indonesia No. Kep.29 / Men / 2012 on the Determination of Coastal Areas and Small Islands Ujungnegoro-Roban Batang Regency in Central Java Province. The coastal park is formed because it meets the criteria in Regulation of Minister of Marine Affairs and Fisheries No. Per.17 / Men / 2008 concerning Conservation Area in Coastal Areas and Small Islands. Ujungnegoro-Roban coastal park potentially damaged coral reef ecosystem, mangrove, abrasion, and sedimentation. Coastal management policy in Ujungnegoro-Roban Coastal Park has been implemented by the Government of Batang Regency such as the installation of artificial reefs and mangrove planting. With the transfer of authority of the coastal park management from the district government to the provincial government, a regional regulation on zoning plan that divides the sea space so as to realize conservation objectives.
\end{abstract}

Keywords: Policy; conservation; coastal areas; protection.

Abstrak

Tujuan artikel ini adalah mengkaji dan menganalisis kebijakan pengelolaan Taman Pesisir Ujungnegoro-Roban.Jenis penelitian ini yaitu penelitian empiris dengan pendekatan kualitatif.Sumber data yang digunakan adalah sumber data primer dan sekunder. Sumber data primer diperoleh melalui wawancara dengan pejabat pada dinas terkait, sedangkan data sekunder diperoleh melalui studi pustaka.Taman Pesisir Ujungnegoro-Roban dibentuk berdasarkan Keputusan Menteri Kelautan dan Perikanan Republik Indonesia Nomor Kep.29/Men/2012 Tentang Penetapan Kawasan Konservasi Pesisir dan Pulau-Pulau Kecil 
Ujungnegoro-Roban Kabupaten Batang di Provinsi Jawa Tengah. Taman pesisir tersebut dibentuk karena memenuhi kriteria dalam Peraturan Menteri Kelautan dan Perikanan Nomor Per.17/Men/2008 tentang Kawasan Konservasi di Wilayah Pesisir dan Pulau-pulau Kecil.Taman pesisir Ujungnegoro-Roban berpotensi mengalami kerusakan ekosistem terumbu karang, mangrove, abrasi, serta sedimentasi.Kebijakan pengelolaan wilayah pesisir di Taman Pesisir Ujungnegoro-Roban sudah dilaksanakan oleh Pemerintah Kabupaten Batang diantaranya dengan pemasangan terumbu karang buatan dan penanaman mangrove.Dengan berpindahnya kewenangan pengelolaan taman pesisir dari pemerintah kabupaten ke pemerintah provinsi, maka diperlukan peraturan daerah tentang rencana zonasi yang membagi ruang laut sehingga dapat mewujudkan tujuan konservasi.

Kata kunci: Kebijakan; konservasi;wilayah pesisir;perlindungan.

\section{A. Pendahuluan}

Indonesia memiliki luas wilayah laut mencakup 70 persen dari total luas wilayah Indonesia (Badan Pusat Statistik Indonesia, 2015). Indonesia juga merupakan salah satu negera kepulauan terbesar di dunia yangmenempati urutan kedua dengan panjang garis pantai $81.000 \mathrm{~km}$ (Kementerian Kelautan dan Perikanan Indonesia, 2017).Sesuai dengan prinsip Deklarasi Djuanda yang menyatakan bahwa selain Indonesia sejak dahulu merupakan negara kesatuan, juga merupakan negara kepulauan yang memiliki corak tersendiri (Ernawati, 2015:4).

Panjangnya garis pantai, banyaknya jumlah pulau dan wilayah perairan yang sangat luas, berpengaruh pada banyaknya kekayaan alam yang dimiliki oleh Indonesia.Kekayaan alam yang menjadi keanekaragaman hayati tersebut salah satunya terdapat di pesisir.Kay dan Adler menyebutkan bahwa pesisir merupakan wilayah yang unik karena dalam konteks bentang alam, wilayah pesisir merupakan tepat bertemunya daratan dan lautan (Kay, R. dan Alde, J, 1999:1).Pengertian lain dari wilayah pesisir sesuai dengan Pasal 1 angka 2 Undang-Undang Nomor 1 Tahun 2014 tentang Perubahan Atas UndangUndang Nomor 27 Tahun 2007 Tentang Pengelolaan Wilayah Pesisir dan Pulau-pulau Kecil adalah daerah peralihan antara ekosistem darat dan laut yang dipengaruhi oleh perubahan di darat dan laut.

Dengan sumber daya laut yang sangat beragam tentunya dapat dimanfaatkan oleh masyarakat Indonesia untuk memperbaiki dan 
meningkatkan perekonomian.Pemanfaatan tersebut tidak dilakukan dengan ekploitasi atau penggunaan berlebihan pada sumber daya laut (Kementerian Kelautan dan Perikanan Indonesia, 2017).Penyelenggaraan penataan ruangperairan pesisir menjadi solusi untuk menentukan arah penggunaan sumber daya pada tiap-tiap satuan perencanaan.Perencanaan tersebut disertai dengan penetapan struktur dan pola ruang pada kawasan perencanaan yang memuat tentang kegiatan yang boleh dan tidak boleh dilakukan serta kegiatan yang boleh dilakukan setelah memperoleh izin.Penataan ruang tersebut diharapkan dapat mewujudkan pembangunan berkelanjutan (sustainable development) yang dapat memadukan pilar ekonomi, sosial budaya, lingkungan dan pemerataan pembangunan.Aspek pembangunan berkelanjutan merupakan hal yang penting, oleh karena itu diperlukan adanya kebijakan yang tepat dalam suatu wilayah (Dian Marliana dkk, 2013:80).

Konservasi menjadi salah satu cara untuk mewujudkan pembangunan berkelanjutan. Pasal 1 angka 18 Undang-Undang Nomor 32 Tahun 2009 tentang Perlindungan dan Pengelolaan Lingkungan Hidupmenyebutkan bahwa konservasi merupakan manajemen udara, air, tanah, mineral ke organisme hidup termasuk manusia sehingga dapat dicapai kualitas kehidupan manusia yang meningkat termasuk dalam kegiatan manajemen adalah survei, penelitian, administrasi, preservasi, pendidikan, pemanfaatan dan latihan. Dalam Pasal 1 angka 7 Peraturan Menteri Kelautan dan Perikanan Nomor Per.17/Men/2008 tentang Kawasan Konservasi di Wilayah Pesisir dan Pulaupulau Kecil, konservasi wilayah pesisir dan pulau-pulau kecil merupakan adalah upaya perlindungan,pelestarian, dan pemanfaatan wilayah pesisir dan pulau-pulau kecil sertaekosistemnya untuk menjamin keberadaan, ketersediaan, dankesinambungan sumber daya pesisir dan pulau-pulau kecil dengan tetapmemelihara dan meningkatkan kualitas nilai dan keanekaragamannya.

Salah satu kawasan konservasi wilayah pesisir dan pulau-pulau kecil yang terdapat di Indonesia adalah Taman Pesisir Ujungnegoro-Roban yang terletak di Kabupaten Batang, Provinsi Jawa Tengah. Taman pesisir 
Ujungnegoro-Roban ditetapkan melalui KeputusanMenteri Kelautan dan Perikanan Republik Indonesia Nomor Kep.29/Men/2012Tentang Penetapan Kawasan Konservasi Pesisir dan Pulau-Pulau KecilUjungnegoro-Roban Kabupaten Batang di Provinsi Jawa Tengah. Pada awalnya, kewenangan pengelolaan taman pesisir Ujugnegoro-Roban terdapat di Pemerintah Kabupaten Batang sesuai dengan Undang-Undang Nomor 32 Tahun 2004 Tentang Pemerintahan Daerah, namun seiring dengan adanya perubahan undang-undang tersebut menjadi Undang-Undang Nomor 23 Tahun 2014 maka kewenangan pengelolaan taman pesisir Ujungnegoro-Roban berpindah ke pemerintah Provinsi Jawa Tengah.

Perpindahan wewenang tersebut tentunya memiliki dampak, diantaranya adalah adanya peralihan meliputi personil, prasarana, maupun dokumentasi. Lalu bagaimanakah proses peralihan tersebut dan kebijakan apa yang diambil oleh pemerintah terkait dengan pengelolaan taman pesisir sebagai kawasan konservasi pesisir dan pulau-pulau kecil?Hal inilah yang dikaji dalam artikel ini.

\section{B. Metode Penelitian}

Penelitian ini menggunakan jenis penelitan empiris.Penelitian empiris dilakukan dengan mencari kebenaran data di lapangan.Sifat penelitian ini adalah penelitian deskriptif."Penelitian deskriptif dimaksudkan untuk memberikan data yang seteliti mungkin mengenai manusia, keadaaan, atau gejala-gejala lainnya" (Soerjono Soekanto, 2008:10).Pendekatan penelitian yang dilakukan penulis adalah pendekatan kualitatif. "Pendekatan kualitatif merupakan tata cara penelitian yang menghasilkan data deskriptif, yaitu apa yang dinyatakan responden secara tertulis atau lisan dari perilaku nyata" (Soerjono Soekanto, 2008:32).

\section{Hasil Penelitian dan Pembahasan}

\section{Taman Pesisir Ujungnegoro-Roban}

Indonesia telah memiliki kawasan konservasi laut seluas 15,7 juta $\mathrm{Ha}$ pada tahun 2013. Salah satunya adalah Taman pesisir Ujungnegoro-Roban yang terletak di Kabupaten Batang, Jawa Tengah.Keberadaan kawasan 
konservasi adalah sebagai upaya untuk memelihara kelestarian fungsi lingkungan hidup dan sumber daya hayati laut.Dari luas tersebut rencana untuk menambah luasan kawasan konservasimenjadi 20 juta Ha pada tahun 2019.

Peraturan Presiden Nomor 2 Tahun 2015 tentang Rencana Pembangunan Jangka Menengah Nasional (RPJMN) tahun 2015-2019 salah satunya berisi tentang arah kebijakan dan strategi pembangunan dengan pengelolaan wilayah pantai secara berkelanjutan dengan mengkombinasikan secara seimbang antara pendekatan non-struktural dan struktural melalui pembangunan pengaman pantai khususnya pada pantai yang terdampak langsung oleh kenaikan muka air laut akibat perubahan iklim, termasuk pulaupulau terdepan untuk menjaga keutuhan wilayah NKRI. Selain itu juga melalui optimalisasi fungsi pengaman pantai yang telah ada, penyusunan zonasi area terbangun dan area publik pantai, pengembangan dan restorasi pantai untuk keperluan preservasi ekosistem dan parawisata, perbaikan sistem monitoring dan pemeliharaan daerah pantai, pembangunan dan revitalisasi pantai.

Pengaturan mengenai wilayah pesisir dalam Rencana Pembangungan Jangka Menengah (RPJMD) Provinsi Jawa Tengah Tahun 2013-2018, diantaranya adalah penentuan kawasan sempadan pantai yaitu daratan sepanjang tepian pantai yang lebarnya proporsional dengan bentuk dan kondisi fisik pantai, minimal 100 meter dari titik pasang tertinggi ke arah darat. Kawasan sempadan pantai direncanakan seluas 8.786 Ha yang terdiri dari kawasan pesisir pantai utara dan pantai selatan. Sempadan pantai diatur dalam Pasal 1 angka 21 Undang-Undang Nomor 27 Tahun 2007 TentangPengelolaan Wilayah Pesisir dan Pulau-Pulau Kecil.

Taman pesisir Ujungnegoro-Roban merupakan satu-satunya kawasan konservasi wilayah pesisir di Provinsi Jawa Tengah yang telah memiliki dasar hukum, yaitu berupa Keputusan Menteri Kelautan dan Perikanan Republik Indonesia Nomor Kep.29/Men/2012 Tentang Penetapan Kawasan Konservasi Pesisir dan Pulau-Pulau Kecil Ujungnegoro-Roban Kabupaten Batang di 
Provinsi Jawa Tengah. Taman pesisir Ujungnegoro-Roban di Kabupaten Batang termasuk dalam salah satu kawasan konservasi wilayah pesisir dan pulau-pulau kecil.Konservasi wilayah pesisir dan pulau-pulau kecil "merupakan upaya perlindungan, pelestarian, dan pemanfaatan wilayah pesisir dan pulau-pulau kecil sesuai dengan ekosistemnya untuk menjamin keberadaan, ketersediaan, dan kesinambungan sumber daya pesisir dengan tetap memelihara dan meningkatkan kualitas nilai dan keanekaragamannya".

Sesuai dengan Keputusan Menteri Kelautan dan Perikanan Republik Indonesia Nomor Kep.29/Men/2012 Tentang Penetapan Kawasan Konservasi Pesisir dan Pulau-Pulau Kecil Ujungnegoro-Roban Kabupaten Batang di Provinsi Jawa Tengah, Taman Pesisir Ujungnegoro-Roban terdiri atas wilayah darat dan laut dengan rincian sebagai berikut :

a. area I seluas 3.961,7 Ha (tiga ribu sembilan ratus enam puluh satu koma tujuh hektar) yang terdiri dari wilayah perairan seluas 3.465,7 Ha (tiga ribu empat ratus enam puluh lima koma tujuh hektar) dan wilayah darat seluas $496 \mathrm{Ha}$ (empat ratus sembilan puluh enam hektar);

b. area II merupakan perairan seluas $15,1 \mathrm{Ha}$ (lima belas koma satu hektar); dan

c. area III merupakan wilayah darat seluas $38,4 \mathrm{Ha}$ (tiga puluh delapan koma empat hektar).

Dengan luas total keseluruhan 4.015,2 Ha (empat ribu lima belas koma dua hektar) yang meliputi wilayah perairan seluas 3.480,8 Ha (tiga ribu empat ratus delapan puluh koma delapan hektar) dan wilayah darat seluas 534,4 $\mathrm{Ha}$ (lima ratus tiga puluh empat koma empat hektar).

Taman Pesisir Ujungnegoro terletak di enam desa pesisir, yaitu Desa Kedungsegog,Desa Ponowareng, Desa Ujungnegoro, Desa Depok , Desa Karanggeneng, serta Desa Klidang Lor (Dinas Kelautan dan Perikanan Kabupaten Batang, 2014:6).Secara administratif, Taman pesisir UjungnegoroRoban berbatasan dengan:

a. sebelah barat: pantai Ujungnegoro (Kecamatan Kandeman);

b. sebelah utara: pantai Laut Jawa; 
c. sebelah timur: pantai Roban Timur (Desa Sengon, Kecamatan Subah); dan

d. sebelah selatan: pantai Ujungnegoro-Roban.

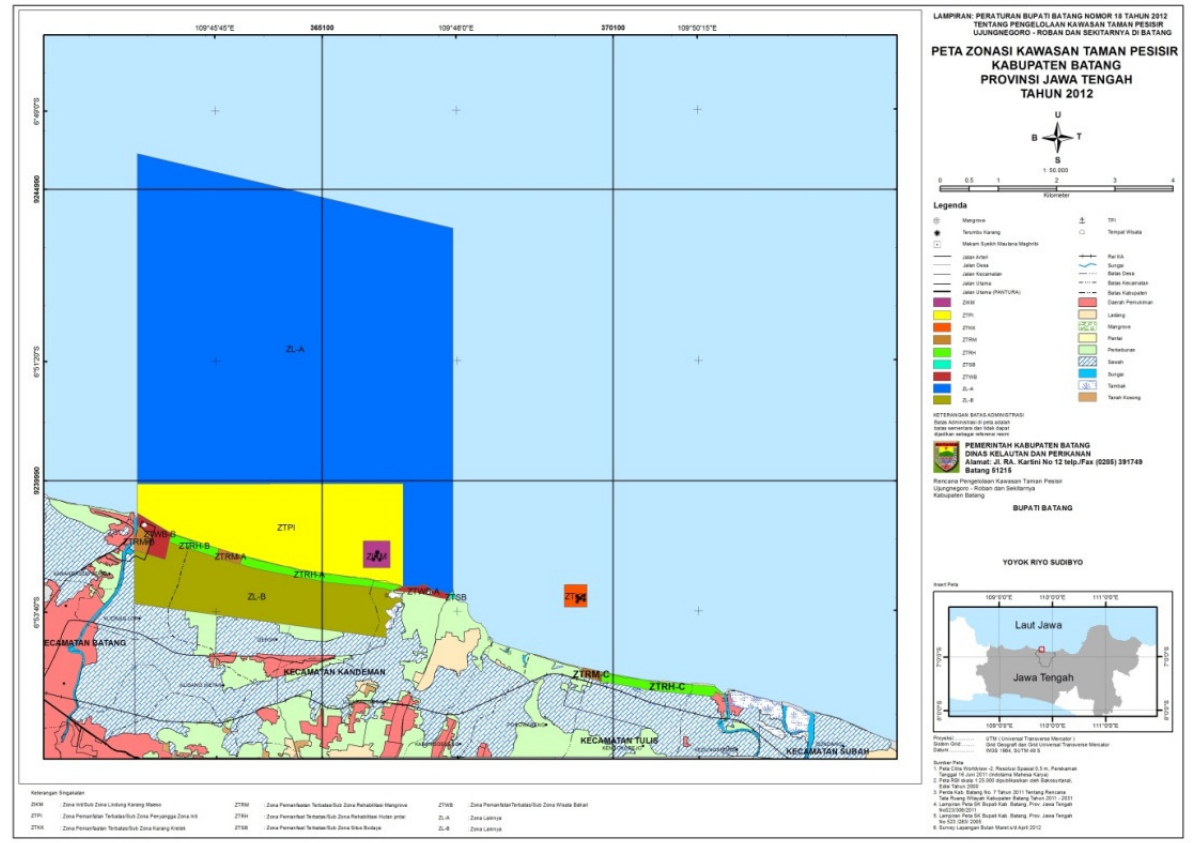

Gambar 1. Peta Zonasi Kawasan Taman Pesisir UjungnegoroRoban Kabupaten Jawa Tengah

Taman pesisir Ujungnegoro-Roban memiliki potensi terumbu karang, mangrove, vegetasi pantai, serta pantai pasir berbatu yang merupakan bentang alam yang khas dan perlu dipertahankan keberadaannya.Ekosistem terumbu karang yang terdapat di Taman pesisir Ujungnegoro-Roban adalah ekosistem karang Maeso dan karang Kretek.Selain menjadi habitat dari berbagai jenis ikan dari famili Serranidae, Lethrinidae, Stolephorus sp., dan Parapriachantus sp. karang Maeso juga menjadi perisai pantai yang dapat meredam ancaman gelombang dan arus air laut.Karang Kretek dengan jenis karang penyusun terumbu didominasi oleh karang masiv dan submasiv yaitu jenis karang Porites dan Favites. Ditemukan juga biota invertebrata antara lain Spon, Gastropoda, cacing laut, Ascidian, dan Bivalvia (tiram kapak) (Badan Lingkungan Hidup Provinsi Jawa Tengah, 2016:II-47). 
Menurut wawancara dengan Kasi Pengelolaan Tempat Pelelangan Ikan (TPI) Dinas Kelautan dan Perikanan Kabupaten Batang, kawasan konservasi dibuat karena kondisi terumbu karang yang kritis. Taman Pesisir Ujungnegoro-Roban yang pada mulanya bernama Kawasan Konservasi Laut Daerah (KKLD) pada tahun 2005 memiliki kondisi terumbu karang yang lebih baik jika dibandingkan dengan kondisi sekarang. Kondisi terumbu karang semakin buruk karena sedimentasi dari sungai Roban yang dipengaruhi oleh aktivitas pertambangan di hulu.

\section{Peralihan Kewenangan dan upaya Pengelolaan Taman Pesisir Ujungnegoro-Roban}

Sebelum diperbarui menjadi Undang-Undang Nomor 23 Tahun 2014 Tentang Pemerintahan Daerah, Undang-Undang Nomor 32 Tahun 2004 mengatur mengenai kewenangan daerah untuk mengelola sumber daya di wilayah laut yang meliputi:

a. eksplorasi, eksploitasi, konservasi, dan pengelolaan kekayaan laut;

b. pengaturan administratif;

c. pengaturan tata ruang;

d. penegakan hukum terhadap peraturan yang dikeluarkan oleh daerah atau yang dilimpahkan kewenangannya oleh Pemerintah;

e. ikut serta dalam pemeliharaan keamanan; dan

f. ikut serta dalam pertahanan kedaulatan negara.

Kewenangan untuk mengelola sumber daya di wilayah laut tersebut paling jauh 12 mil laut diukur dari garis pantai ke arah laut lepas dan/atau ke arah perairan kepulauan untuk provinsi dan 1/3 dari wilayah kewenangan provinsi untuk kabupaten/kota yaitu 0-4 mil.

Setelah adanya Undang-Undang Nomor 23 Tahun 2014 tentang Pemerintahan Daerah sebagai pengganti Undang-Undang Nomor 32 Tahun 2004, maka pemerintah daerah kabupaten/kota tidak lagi memiliki kewenangan untuk mengelola wilayah laut. Pemerintah daerah kabupaten hanya memiliki kewenangan di bidang perikanan tangkap dan perikanan budidaya.Undang-Undang Nomor 23 Tahun 2014 Tentang Pemerintahan 
Daerah mengatur mengenai pengelolaan kelautan, pesisir, dan pulau-pulau kecil yang pembagian urusannya diserahkan kepada pemerintah daerah provinsi. Urusan tersebut terkait :

a. Pengelolaan ruang laut sampai dengan 12 mil di luar minyak dan gas bumi;

b. Penerbitan izin dan pemanfaatan ruang laut di bawah 12 mil di luar minyak dan gas bumi; dan

c. Pemberdayaan masyarakat pesisir dan pulau-pulau kecil.

Berpindahnya kewenangan pengelolaan Taman Pesisir UjungnegoroRoban dari Pemerintah Kabupaten Batang ke Pemerintah Provinsi Jawa Tengah, maka diperlukan peraturan daerah yang mengatur mengenai wilayah pesisir dan pulau-pulau kecil khususnya terkait dengan pemetaan ulang ruang laut. Penataan ruang laut tersebut diperlukan karena pada awalnya pemerintah provinsi hanya mengelola ruang laut sejauh 4 sampai dengan 12 mil dan saat ini menjadi 0 sampai dengan 12 mil. Adanya tambahan ruang laut 0-4 mil pada awalnya merupakan kewenangan dari pemerintah kabupaten, sekarang kewenangannya berpindah pada pemerintah provinsi. Sehingga luas ruang laut provinsi tidak lagi dimulai dari titik 4 mil tetapi dari titik 0 mil sampai dengan 12 mil.Sebelum membentuk suatu peraturan daerah yang baru, terdapat masa transisi atau perpindahan yang terjadi dari awal tahun 2015 hingga akhir tahun 2016. Perpindahan tersebut meliputi penyerahan aset, personil (sumber daya manusia), serta program-program baik yang belum terlaksana maupun yang masih dalam proses pelaksanaan.

Pembentukan suatu kebijakan dalam hal ini adalah Peraturan Daerah Provinsi Jawa Tengah tentang Rencana Zonasi Wilayah Pesisir dan Pulaupulau Kecil melalui berbagai tahap. Menurut William N. Dunn, kebijakan memiliki tahap-tahap sebagai berikut (William N. Dunn, 2000:22):

a. Tahap penyusunan agenda

Sejumlah aktor yang dipilih dan diangkat untuk merumuskan masalah-masalah pada agenda publik.Sebelumnya masalah-masalah ini berkompetisi terlebih dahulu untuk dapat 
masuk ke dalam agenda kebijakan, karena tidak semua masalah menjadi prioritas dalam agenda kebijakan publik.Pada akhirnya, beberapa masalah masuk ke agenda kebijakan para perumus kebijakan. Pada tahap ini suatu masalah mungkin tidak disentuh sama sekali, sementara masalah lain ditetapkan menjadi fokus pembahasan, atau ada pula masalah karena alasan-alasan tertentu ditunda untuk waktu yang lama.

b. Tahap formulasi kebijakan

Masalah yang telah masuk ke agenda kebijakan kemudian dibahas oleh para aktor pembuat kebijakan.Masalah-masalah tersebut kemudian didefinisikan untuk kemudian dicari solusi pemecahan masalah terbaik.Pemecahan masalah tersebut berasal dari berbagai alternatif atau pilihan kebijakan dengan perjuangan suatu masalah untuk masuk ke dalam agenda kebijakan, dalam tahap perumusan kebijakan masing-masing alternatif bersaing untuk dapat dipilih sebagai tindakan yang diambil untuk memecahkan masalah. Pada tahap ini, masing-masing aktor akan "bermain" untuk mengusulkan pemecahan masalah tersebut.

c. Tahap adopsi kebijakan

Berbagai macam alternatif kebijakan yang ditawarkan oleh paraaktor perumus kebijakan, pada akhirnya salah satu dari alternatif kebijakan tersebut diadopsi untuk tindakan lebih lanjut dalam kebijakan publik dengan dukungan dari mayoritas legislatif, konsensus antara direktur lembaga atau keputusan peradilan.

d. Tahap implementasi kebijakan

Suatu program kebijakan hanya akan menjadi catatancatatam elit, jika program tersebut tidak diimplementasikan. Oleh karena itu, keputusan program kebijakan yang telah diambil sebagai alternatif pemecahan masalah harus diimplementasikan, yakni dilaksanakan oleh badan-badan pemerintah di tingkat bawah.Kebijakan yang telah diambil dilaksanakan oleh badan- 
badan pemerintah yang memobilisasi sumberdaya finansial dan manusia. Pada tahap implementasi ini muncul berbagai kepentingan yang akan saling bersaing. Beberapa implementasi kebijakan mendapat dukungan para pelaksana mungkin akan ditentang oleh para pelaksana.

e. Tahap evaluasi kebijakan

Pada tahap ini kebijakan yang telah dijalankan akan dinilai atau dievaluasi, hal ini dilakukan untuk melihat sejauh mana kebijakan yang dibuat telah mampu memecahkan masalah. Kebijakan publik pada dasarnya dibuat untuk meraih dampak yang diinginkan.Dalam hal ini, memecahkan masalah yang dihadapi masyarakat.Oleh karena itu, ditentukanlah ukuran-ukuran atau kriteria-kriteria yang menjadi dasar untuk menilai apakah kebijakan publik telah meraih dampak yang diinginkan.

Secara umum suatu kebijakan dianggap berkualitas dan mampu dilaksanakan bila mengandung beberapa elemen, yaitu (Said Zainal Abidin, 2002:12):

a. Tujuan yang ingin dicapai atau alasan yang dipakai untuk mengadakan kebijakan itu, dimana tujuan suatu kebijakan dianggap baik apabila tujuannya:

1) Rasional, yaitu tujuan dapat dipahami atau diterima oleh akal yang sehat. Hal ini terutama dilihat dari faktor-faktor pendukung yang tersedia, dimana suatu kebijakan yang tidak mempertimbangkan faktor pendukung tidak dapat dianggap kebijakan yang rasional.

2) Diinginkan (desirable), yaitu tujuan dari kebijakan menyangkut kepentingan orang banyak, sehingga mendapat dukungan dari banyak pihak.

b. Asumsi yang dipakai dalam proses perumusan kebijakan itu realistis, asumsi tidak mengada-ada. Asumsi juga menentukan tingkat validitas suatu kebijakan. 
c. Informasi yang digunakan cukup lengkap dan benar, dimana suatu kebijakan menjadi tidak tepat jika didasarkan pada informasi yang tidak benar atau sudah kadaluarsa.

Pemerintah Kabupaten Batang melakukan upaya konservasi untuk perlindungan dan pengelolaan lingkungan di Taman Pesisir UjungnegoroRoban dengan membuat kebijakan.Menurut teori implementasi kebijakan dari Merilee S. Grindle (AG.Subarsono, 2011:93), ada dua hal yang menjadi pengaruh dalam implementasi kebijakan yaitu isi kebijakan (content of policy) dan lingkungan implementasi (context of implementatition). Isi kebijakan dipengaruhi oleh:

a. Sejauh mana kepentingan kelompok sasaran termuat dalam isi kebijakan.

Kepentingan yang terpengaruhi oleh kebijakan menyangkut sejauh mana kepentingan kelompok sasaran atau target groups termuat dalam isi kebijakan. Kepentingan tersebut berkaitan dengan berbagai kepentingan yang memiliki pengaruh terhadap suatu implementasi kebijakan.Indikator ini memiliki argumen bahwa dalam pelaksanaan sebuah kebijakan pasti melibatkan banyak kepentingan, dan sejauh mana pengaruh yang dibawa oleh kepentingan-kepentingan tersebut terhadap implementasinya.

b. Jenis manfaat yang diterima oleh kelompok sasaran.

Dalam konten kebijakan, manfaat kebijakan berupaya untuk menunjukkan dan menjelaskan bahwa di dalam sebuah kebijakan harus terdapat beberapa jenis manfaat yang memuat dan menghasilkan dampak positif oleh pengimplementasian kebijakan yang akan dilaksanakan.Jenis manfaat yang diterima oleh masyarakat dalam implementasi kebijakan pengelolaan Taman Pesisir Ujungnegoro-Roban adalah meningkatnya kapasitas ekonomi nelayan dan kelompok usaha, hal ini disebabkan oleh membaiknya kondisi terumbu karang sehingga menjadi habitat yang sesuai bagi ikan dan biota lainnya. 
c. Sejauh mana perubahan yang diinginkan dari sebuah kebijakan Derajat perubahan yang ingin dicapai menunjukkan seberapa besar perubahan yang hendak atau ingin dicapai melalui adanya sebuah implementasi kebijakan harus memiliki skala yang jelas.Perubahan yang diinginkan dari upaya konservasi Taman Pesisir UjungnegoroRoban adalah perbaikan kondisi terumbu karang yaitu Karang Maeso dan Karang Kretek seperti kondisi semula.

d. Apakah letak sebuah program sudah tepat.

Pengambilan sebuah keputusan di dalam sebuah kebijakan memegang peranan penting dalam pelaksanaan sebuah kebijakan, oleh karena itu pada bagian ini harus dijelaskan dimana letak pegambilan keputusan dari suatu kebijakan yang akan diimplementasikan.Program-program yang terwujud dari kebijakan pemerintah Kabupaten Batang yaitu pemasangan terumbu karang buatan, penanaman mangrove, serta pemasangan rumah ikan sudah tepat.Program tersebut bertujuan untuk memperbaiki kondisi Taman Pesisir Ujungnegoro-Roban sehingga tujuan konservasi dapat tercapai.

e. Apakah sebuah kebijakan telah menyebutkan implementornya secara rinci, dalam melaksanakan suatu kebijakan atau program harus didukung dengan adanya pelaksana kebijakan yang memiliki kompetensi dan capable demi keberhasilan suatu kebijakan. Pelaksana kebijakan dalam pengelolaan Taman Pesisir UjungnegoroRoban adalah Dinas Kelautan dan Perikanan Kabupaten Batang.

f. Apakah sebuah program didukung oleh sumberdaya yang memadai. Apakah sebuah program didukung dengan sumberdaya yang memadai.Pelaksanaan suatu kebijakan juga harus didukung dengan sumberdaya yang memadai dengan tujuan agar pelaksanaannya dapat berjalan dengan baik.Sumberdaya yang ada terkait anggaran sudah mencukupi untuk program pemasangan terumbu karang, penanaman mangrove, dan pemasangan rumah ikan, tetapi anggaran masih 
kurang dalam program pembuatan pemecah gelombang laut.Sumberdaya manusia yang dimiliki oleh Dinas Kelautan dan Perikanan sudah memadai.

Sedangkan lingkungan implementasi dipengaruhi oleh:

a. Seberapa besar kekuasaan, kepentingan, dan strategi yang dimiliki oleh para aktor yang terlibat dalam implementasi kebijakan. Dalam sebuah kebijakan perlu untuk diperhitungkan mengenai kekuatan atau kekuasaan, kepentingan, serta strategi yang digunakan oleh para aktor yang terlibat guna melancarkan pelaksanaan suatu implementasi kebijakan.

b. Karakteristik lembaga dan penguasa, bagaimanakah keberadaan institusi dan rezim yang sedang berkuasa. Lingkungan dimana suatu kebijakan tersebut dilaksanakan juga memiliki pengaruh terhadap keberhasilannya, maka pada bagian ini dijelaskan bagaimana karakteristik dari suatu lembaga yang akan turut mempengaruhi suatu kebijakan.

c. Tingkat kepatuhan dan daya tanggap (responsivitas) kelompok sasaran. Kepatuhan dan respon dari para pelaksana juga dirasa menjadi sebuah aspek penting dalam proses pelaksanaan suatu kebijakan, maka yang hendak dijelaskan pada poin ini adalah sejauhmanakah kepatuhan dan respon dari pelaksana dalam menanggapi suatu kebijakan.

Kebijakan yang dibuat oleh Dinas Kelautan dan Perikanan Kabupaten Batang tersebut terwujud dalam program berupa rencana pembuatan pemecah gelombang, pemasangan rumah ikan, pemasangan terumbu karang buatan, serta penanaman mangrove. Program-program tersebut kemudian dilaksanakan pada tahun 2013 hingga 2015.Selain program yang diprakarsai oleh Pemerintah Kabupaten Batang, program untuk mendukung konservasi Taman Pesisir Ujungnegoro-Roban juga dilakukan oleh PT. Bhimasena Power Indonesia. PT. Bhimasena Power Indonesia merupakan perusahaan yang melaksanakan operasional Pembangkit Listrik Tenaga Uap (PLTU) batubara 
yang sedang dalam proses pembangunan di Ujungnegoro. PT. Bhimasena Power Indonesia sejak tahun 2012 telah melakukan kegiatan pengelolaan lingkungan terutama di kawasan konservasi pesisir dan pulau-pulau kecil di Taman Pesisir Ujungnegoro-Roban.Kegiatan tersebut diantaranya adalah penenggelaman rumah ikan buatan dan penanaman mangrove.

Sampai dengan bulan Oktober 2017, Dinas Kelautan dan Perikanan Provinsi Jawa Tengah masih berada dalam tahap penyusunan atau formulasi kebijakan peraturan daerah Provinsi Jawa Tengah tentang Rencana Zonasi Wilayah Pesisir dan Pulau-pulau Kecil. Proses penyusunan peraturan daerah tersebut sudah masuk dalam pansus Dewan Perwakilan Rakyat Daerah (DPRD) Provinsi Jawa Tengah. Proses penyusunan Peraturan Daerah Provinsi Jawa Tengah tentang Rencana Zonasi Wilayah Pesisir dan Pulau-pulau Kecil dimulai pada tahun 2016 yang diawali dengan kajian sumber daya pesisir.

Dinas Kelautan dan Perikanan Provinsi Jawa Tengah telah membentuk Balai Pengawasan dan Konservasi Sumber Daya Kelautan dan Perikanan yang terdiri dari wilayah barat dan timur. Wilayah barat meliputi Pemalang, Brebes, Tegal, Kebumen, Cilacap, Purworejo dan Wonogiri, sedangkan wilayah timur meliputi Pekalongan, Batang, Kendal, Semarang, Demak, Jepara, Pati dan Rembang. Balai Pengawasan dan Konservasi Sumber Daya Kelautan dan Perikanan ini nantinya akan menjadi pelaksana program Dinas Kelautan dan Perikanan Provinsi Jawa Tengah mulai tahun 2018.

Dinas Kelautan dan Perikanan Provinsi Jawa Tengah mengalami kendala berupa kurangnya sumber daya manusia sebagai pengawas dan pelaksana program di daerah kabupaten.Dengan cakupan wilayah yang luas jumlah sumber daya manusia yang dimiliki oleh Dinas Kelautan dan Perikanan Provinsi Jawa Tengah mengalami ketidakseimbangan. Berikut adalah kondisi luas 12 mil laut Provinsi Jawa Tengah:

\begin{tabular}{|c|c|c|c|c|}
\hline \multirow{2}{*}{ No. } & \multirow{2}{*}{ Wilayah } & \multirow{2}{*}{ Keterangan } & \multicolumn{2}{|c|}{ Luas } \\
\cline { 4 - 5 } & & & $\mathrm{Ha}$ & $\mathrm{Km}^{2}$ \\
\hline 1. & Pantai Utara Timur & Demak-Rembang & 946897.17 & 9468.97173 \\
\hline
\end{tabular}




\begin{tabular}{|c|l|l|l|l|}
\hline 2. & Pantai Utara Timur & Demak Rembang & 828870.24 & 8288.70 \\
\hline 3. & Pantai Utara Barat & Brebes-Semarang & 426766.67 & 4267.67 \\
\hline 4. & $\begin{array}{l}\text { Pantai Selatan } \\
\text { Timur }\end{array}$ & $\begin{array}{l}\text { Kebumen- } \\
\text { Wonogiri }\end{array}$ & 180746.27 & 1807.46 \\
\hline 5. & Pantai Selatan Barat & Cilacap & 167482.31 & 1674.82 \\
\hline
\end{tabular}

Sumber: Dinas Kelautan dan Perikanan Provinsi Jawa Tengah.

Rincian luas 12 mil laut per kabupaten di Provinsi Jawa Tengah:

\begin{tabular}{|c|c|c|c|c|}
\hline \multirow{2}{*}{ No. } & \multirow{2}{*}{ Wilayah } & \multirow{2}{*}{ Keterangan } & \multicolumn{2}{|c|}{ Luas } \\
\hline & & & $\mathrm{Ha}$ & $\mathrm{Km}^{2}$ \\
\hline 1. & Pantai Utara Barat & Brebes & 69242.21 & 692.42 \\
\hline 2. & Pantai Utara Barat & Kota Tegal & 17475.64 & 174.76 \\
\hline 3. & Pantai Utara Barat & Tegal & 42135.70 & 421.36 \\
\hline 4. & Pantai Utara Barat & Pemalang & 78506.32 & 785.06 \\
\hline 5. & Pantai Utara Barat & Pekalongan & 17514.93 & 175.15 \\
\hline 6. & Pantai Utara Barat & Kota Pekalongan & 14124.13 & 141.24 \\
\hline 7. & Pantai Utara Barat & Batang & 72385.11 & 723.85 \\
\hline 8. & Pantai Utara Barat & Kendal & 82943.18 & 829.43 \\
\hline 9. & Pantai Utara Barat & Semarang & 32439.45 & 324.39 \\
\hline 10. & Pantai Utara Timur & Demak & 58786.79 & 587.87 \\
\hline 11. & Pantai Utara Timur & Jepara & 514426.54 & 5144.27 \\
\hline 12. & Pantai Utara Timur & $\begin{array}{l}\text { Jepara (tanpa TN } \\
\text { Karimunjawa) }\end{array}$ & 632453.48 & 6324.53 \\
\hline 13. & Pantai Utara Timur & Pati & 108955.85 & 1089.56 \\
\hline 14. & Pantai Utara Timur & Rembang & 146701.05 & 1467.01 \\
\hline 15. & Pantai Selatan Barat & Cilacap & 179968.64 & 1799.69 \\
\hline 16. & Selatan & Kebumen & 118877.08 & 1188.77 \\
\hline 17. & $\begin{array}{ll}\text { Pantai } & \text { Selatan } \\
\text { Timur } & \end{array}$ & Purworejo & 50816.76 & 508.7 \\
\hline 18. & Selatan & Wonogiri & 11052.43 & 110.52 \\
\hline
\end{tabular}


\begin{tabular}{|l|l|l|l|l|}
\hline & Timur & & & \\
\hline
\end{tabular}

Sumber: Dinas Kelautan dan Perikanan Provinsi Jawa Tengah.

Belum adanya dasar hukum tentang penataan ruang laut di Provinsi Jawa Tengah mengakibatkan tertundanya penyusunan dan pelaksanaan program konservasi di Taman Pesisir Ujungnegoro-Roban.Namun, di wilayah konservasi Taman Pesisir Ujungnegoro-Roban Kabupaten Batang terdapat Kelompok Masyarakat Pengawas yang terdiri dari nelayan serta pemerhati lingkungan yang fokus pada permasalahan pesisir.Kelompok masyarakat pengawas ini dilibatkan dalam pembentukan kebijakan oleh pemerintah daerah.Selain itu, mereka juga ikut aktif dalam pengawasan Taman Pesisir Ujungnegoro-Roban dan melaporkan apabila terjadi pelanggaran seperti nelayan yang keluar dari area penangkapan ikan dan memasuki area konservasi, sehingga kawasan konservasi Taman Pesisir Ujungnegoro-Roban tetap terjaga kelestariannya.

\section{Simpulan}

1. Dinas Kelautan dan Perikanan Provinsi Jawa Tengah belum dapat membuat dan melaksanakan program terkait dengan pengelolaan konservasi wilayah pesisir Taman Pesisir Ujungnegoro-Roban karena peraturan daerah Provinsi Jawa Tengah tentang Rencana Zonasi Wilayah Pesisir dan Pulau-pulau Kecil di Jawa Tengah belum selesai.

2. Berpindahnya wewenang pengelolaan wilayah pesisir termasuk Taman Pesisir Ujungnegoro-Roban dari pemerintah Kabupaten Batang ke Pemerintah Provinsi Jawa Tengah mengalami kendala yaitu kurangnya sumber daya manusia yang dapat melakukan pengawasan di Taman Pesisir Ujungnegoro-Roban.

\section{E. Saran}

1. DPRD Provinsi Jawa Tengah dan Gubernur Provinsi Jawa Tengah perlu segera mengesahkan Rencana Peraturan Daerah Provinsi Jawa Tengah tentang Rencana Zonasi Wilayah Pesisir dan Pulau-pulau Kecil terutama mengenai pembagian ruang laut, khususnya pengelolaan Taman Pesisir Ujungnegoro-Roban, berdasarkan Undang-Undang Nomor 27 Tahun 2007 
Tentang Pengelolaan Wilayah Pesisir dan Pulau-pulau Kecil dan Peraturan Menteri Kelautan dan Perikanan Republik Indonesia Nomor Per.17/Men/2008 Tentang Kawasan Konservasi di Wilayah Pesisir dan Pulau-Pulau Kecil.

2. Dinas Kelautan dan Perikanan Provinsi Jawa Tengah perlu memaksimalkan peran kelompok masyarakat pengawas agar melakukan pengawasan yang intensif terhadap pelaku pelanggaran yang melanggar larangan untuk memasuki kawasan inti di Taman Pesisir UjungnegoroRoban agar kawasan konservasi tetap terjaga kelestariannya.

\section{Daftar Pustaka}

AG.Subarsono. 2011.Analisis Kebijakan Publik: Konsep, Teori dan Aplikasi. Yogyakarta: Pustaka Pelajar.

Kay, R. dan Alde, J. 1999.Coastal Management and Planning.New York : E \&FN Spon.

Said Zainal Abidin. 2002. Kebijakan Publik. Jakarta: Yayasan Pancur Siwah.

Soerjono Soekanto. 2008. Pengantar Penelitian Hukum. Jakarta: UI Press.

William N. Dunn. 2000. Pengantar Analisis Kebijakan Publik. Yogyakarta: Gajah Mada University Press.

Dian Marliana, Sarwono, dan Mochammad Rozikin.2013. "Kebijakan Pengelolaan Wilayah Pesisir Berbasis Sustainable Development di Kabupaten Sampang (Studi pada Bappeda Kabupaten Sampang)". Jurnal Administrasi Publik. Volume 1 Nomor 3.

Ernawati. 2015. "Implementasi Deklarasi Djuanda dalam Perbatasan Perairan Lautan Indonesia". Prosiding Seminar Nasional Multi Disiplin Ilmu \& Call For Papers Unisbank Kajian Multi Disiplin Ilmu untuk Mewujudkan Poros Maritim dalam Pembangunan Ekonomi Berbasis Kesejahteraan Rakyat.

Badan Pusat Statistik Indonesia, "Luas Daerah dan Jumlah Pulau Menurut Provinsi,2002-2015”, https://www.bps.go.id/linkTabelStatis/view/id/1366, diakses pada Senin, 28 Agustus 2017 pukul 22.22 WIB.

Kementerian Kelautan dan Perikanan Indonesia, "Langkah Indonesia Menjadi Poros Maritim Dunia Demi Impian RI", http://kkp.go.id/, diakses pada Sabtu, 21 Oktober 2017 pukul 12.27 WIB.

Badan Lingkungan Hidup Provinsi Jawa Tengah. 2016. Draft Laporan Akhir: Penyiapan Penyusunan Baku Kerusakan Terumbu Karang dan Padang Lamun di Jawa Tengah Tahun 2016. 
Undang-Undang Nomor 32 Tahun 2009 Tentang Perlindungan dan Pengelolaan Lingkungan Hidup.

Undang-Undang Nomor 27 Tahun 2007 Tentang Pengelolaan Wilayah Pesisir dan Pulau-Pulau Kecil.

Undang-Undang Nomor 23 Tahun 2014 Tentang Pemerintahan Daerah.

Peraturan Presiden Nomor 2 Tahun 2015 Tentang Rencana Pembangunan Jangka Menengah Nasional (RPJMN) tahun 2015-2019.

Keputusan Menteri Kelautan dan Perikanan Republik Indonesia Nomor Kep.29/Men/2012 Tentang Penetapan Kawasan Konservasi Pesisir dan Pulau-Pulau Kecil Ujungnegoro-Roban Kabupaten Batang di Provinsi Jawa Tengah. 